\title{
Applications of Three Dimensional Finite Element Method in Orthodontics
}

Vishali Prakash ${ }^{1}$, Sumathi Felicita A $^{2}$

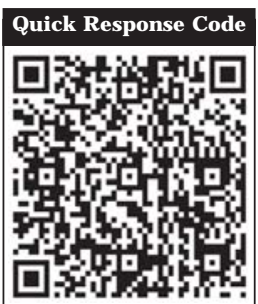

doi: $10.5866 / 2014.641681$

${ }^{1 \& 2}$ Department of Orthodontics

Saveeetha Dental College

Chennai.

\section{Article Info:}

Received: J uly 12, 2014

Review Completed: August 10, 2014

Accepted: November 11, 2014

Available Online: J anuary, 2015 (www.nacd.in)

(C) NAD, 2015 - All rights reserved

\section{Email for correspondence:}

vishaliprakash1591@gmail.com

\begin{abstract}
:
The aim of this paper is to enumerate the various applications of 3D finiteelement method in Orthodontics. A literature search was done in pub med, embase and cochrane. All articles related to the application of 3D finite element in orthodontics were collected. The articles were categorized into various subheadings based on their use. The various applications of 3D finite element method in orthodontics have been described in a systematic manner.
\end{abstract}

Key words: 3D Finite element method, orthodontics, application

\section{INTRODUCTION:}

Finite element method (FEM) was developed in 1940 for use in civil and aerospace engineering. Yettram et al introduced this tool in orthodontics in 1972. ${ }^{1}$ FEM in orthodontics is used to analyze the structural stress and is considered to be a highly precise technique. An accurate model of tooth and its surrounding structures is offered by this method.

\section{Materials and Method:}

A literature search was done in pub med, Embase and Cochrane. All articles related to the application of 3D finite element in orthodontics were collected. The articles were categorized into various subheadings based on their use.

\section{FEM in Maxillary Protraction:}

Dong $\mathrm{R}$ et al established a three dimensional finite element model of the crani ofacial complex and analysed the force direction of protraction on the temperomandibular joint. ${ }^{2}$ The force applied on the chin was $5 \mathrm{~N}$.The angle of force direction was $40^{*}$ relative to the occlusal plane when the stress and displacement was relatively small.

\section{Indian Journal of Dental Advancements Journal homepage: www. nacd. in}


Liu cet al analyzed the maxillary growth based on the labiolingual appliance during the maxillary protraction treatment cycle. ${ }^{3} \mathrm{~A}$ three dimensional stimulation of labiolingual appliance was performed.

Yanx et al analyzed the bio mechanical effects on the cranio maxillary complex of bone during maxillary protraction. ${ }^{4}$ The direction of forces were 0*, 10*, 20*and 30* forward and downward relative to the occlusal plane.

The bio mechanical effects of maxillary protraction was also investigated by Chen zx et al with and without maxillary expansion on a model of unilateral cleft lip and palate before and after alveolar bone graft. ${ }^{5}$

\section{FE $M$ and Arch Wire Activation:}

Canales et al birth death technique in orthodontic brackets proved to be a bio mechanical stimulation for placement of continuous arch wires. ${ }^{6}$

De Oliveira BF et al established that greater tooth displacement was found in shortened dental arches than in complete dental arches. ${ }^{7}$ An increase in arch perimeter was associated with mandibular lateral expansion. ${ }^{8}$ Inter molar expansion of $1 \mathrm{~mm}$ increased the arch perimeter by $0.30 \mathrm{~mm}$. In sliding mechanics a three dimensional finite element analysis was used by Tominaga et al to simulate en masse anterior tooth retraction. ${ }^{9}$ On the application of retraction force the displacement of maxillary incisor and arch wire deformation were calculated. An $x$ et al investigated the effect of en masse retraction of maxillary teeth and established that excessive retraction can be avoided and intrusion and torque control can be achieved. ${ }^{10}$

\section{FEM and Mini -Implants:}

Holberg $\mathrm{N}$ et al found that when indirect miniimplant anchorage was used, FEM results revealed high loads on dental anchorage. ${ }^{11} \mathrm{Holberg} C$ et al revealed that bio cortical implant anchorage is more favourable biomechanically than mono cortical anchorage. ${ }^{12}$

Ludwig B et al analysed rapid palatal expansion with hybrid Hyrax appliance and stated that it is a suitable device as it delivered a force at the resistance of the nasomaxillary complex through the 2 mini implants. ${ }^{13}$

Maxillary expansion was attempted in adult patients with fused inter maxillary sutures and was evaluated by Boryor $\mathrm{A}$ et al. ${ }^{14} \mathrm{Mini}$-implant supported expansion screw of the inter maxillary suture showed a high tensile stress concentration by finite element simulation. An expansion force of $86 \mathrm{~N}$ was established when there was a strain measurement on one of the expansion screws.

Neinkemper $M$ investigated primary and secondary displacement of teeth. ${ }^{15}$ Controlled tipping and bodily movement were observed as frequent type of movements. Lin TS et al observed a high bone stress adjacent to the mini implants in relation to increased exposure length. ${ }^{16}$

Mini-implant deflection and stress distribution was evaluated by Meher $\mathrm{AH}$ et al using FEM. ${ }^{17}$ Lee et al tried to establish a correlation between the influence of placement angle and theapplication of orthopedic force. ${ }^{18}$ Thestability of mini-implants was reduced when the placement angles was less than 60* with various directions of orthopedic forces. The stability of orthodontic mini-implants was estimated using mandibular deformation under clenching. ${ }^{19}$

The biomechanical differences between the direct and indirect anchorage and it's effects on the primary stability of mini- implants was analyzed by $\mathrm{HolbergC}$ et al. ${ }^{20}$ An indirect anchorage was chosen to minimize the risk of losing the miniimplant in case of major orthodontic forces.

Therelationship between the force direction and movement patterns was analyzed by Kojima $Y$ et al. ${ }^{21}$ The effect of force direction on movement patterns was demonstrated by mechanical simulations.

The bone stress was investigated by Huang YW et al when mini-implants were used for orthodontic anchorage. ${ }^{22}$ The bone stress was linearly proportional to the force magnitude. The application of force in the forward direction resulted in highest values. 
Lee et al evaluated stress distribution in Mandibular molar region. ${ }^{23}$ Slightly less displacement was appreciated in the angled orthodontic mini- implants(OMIs) than the OMI placed at 90*. The maximum $V$ on Mises stress increased with the inclination of the loading direction.

\section{FE M and Alveolar Bone:}

3-D finite element model of maxillary first molars was established by Wang $\mathrm{H}$ et al and the stress magnitude and distribution within the Periodontal ligament of maxillary first molars was calculated when loaded with intrusion force. ${ }^{24}$

\section{FEM and T-Loops:}

The commonly analyzed parameter when segmental T-loop was used for canine retraction is ideal moment to force ratio. The load system was significantly affected due to clinical changes in canine position and angulation. The highest moment to force ratio (8.5-9.3) was showed by upright Opus loops and I-loops, when the loops were centred on the canine brackets.

\section{FEM and Trans Palatal Bar and Twin Block:}

Transpalatal arch design was used to optimize unilateral molar rotation correction using a finite element method by Geramy $A$ et al. ${ }^{25}$ An activation of about 0.1 and $1.0 \mathrm{~mm}$ produced the same increasing patterns regarding the energy levels.

\section{FEM and Root Resorption:}

The initial effects of stress on the periodontal ligament was compared over time in orthodontic external root resorption, necrosis and TRAP+cell population. ${ }^{26}$

\section{FEM and Expanders:}

Araugio RM et al analysed that less dental tipping was generated when theideal screw position is slightly above the maxillary first molar center of resistance. ${ }^{27}$

\section{FE M in Orthognathic Surgery:}

The hybrid technique fixation of the Sagittal split ramus osteotomy was evaluated by SatoFR et al for their mechanical characteristics and stress distribution. ${ }^{28}$

\section{Fem in Individual Tooth Movements:}

Van Schepdael et al analyzed and concluded that the differences between analytical and FEM results were small except at the alveolar crest region, but a success in the global behaviour of PDL was observed. ${ }^{29}$

Vikram NR et al established an increase in cementum thicknesss when the apical stress induced in the periodontal ligament decreased. ${ }^{30} \mathrm{~A}$ stress in the cementum and Periodontal ligament occurred as a result of clinical delivery of an orthodontic force.

Lin YL et al found that there was a higher stress level and homogenous stress distribution in individual teeth with posterior cross bite than teeth with normal occlusion. ${ }^{31}$

Geramy A analyzed a method to move palatally erupted lateral incisors labially. ${ }^{32}$ Equal forces of about $0.15 \mathrm{~N}$ were applied. An intrusive component could also be added.

\section{FEM in Brackets:}

The bracket design had less influence on the torquing moment. ${ }^{33}$ An increased torque control capability was exhibited by wider brackets. Holberg $C$ et al attempted to create an anisotropic finite element method model of mandibular bone and orthodontic bracket. ${ }^{34}$ Theresults indicated that the risk of enamel fracture depended on the individual debonding procedure.

\section{FEM in Tip Edge Force System:}

Zhang $Y$ et al analyzed the distal and extrusive displacement of maxillary first molar under the effect of tip back bend, which could be controlled by the precise control of the degree and position of tip back bend. ${ }^{35}$

\section{FEM in Soft Tissues:}

Chen $\mathrm{S}$ et al did a study to get individualized facial three dimensional FE model for prediction of treatment - related morphological change of facial soft tissue. Hefound an average deviation of $0.47 \mathrm{~mm}$ and $0.75 \mathrm{~mm}$ in the soft and hard tissue respectively. ${ }^{36}$ 


\section{Conclusion:}

FEM has several applications in orthodontics. Since the finite element method can be used innumerable ways to determine stress pattern for hypothetical situations, it's applications in orthodontics is manifold.

\section{References}

1. Yettram AL,Wright KWJ ,Houston WJ B.Center of rotation of a maxillary central incisor under orthodontic loading. $\mathrm{Br}$ J Orthod 1977; 4:23-27.

2. Dong R, WaTTRAMng XX, Zhang WJ, Li J, Zheng DH, Zhang J. Three-dimensional finite element analysis of different reactive force direction of maxillary protraction on temporomandibular joint. Zhonghua Kou Qiang Yi Xue Za Zhi. 2013; 48:740-744.

3. Liu C, Zhu X, Zhang X, Guo J , Tang G. Three-dimensional finite-element analysis of maxillary protraction based on labiolingual appliance.Hua Xi Kou Qiang Yi Xue Za Zhi. 2013; 31:457-462.

4. Yan X, He W, Lin T, Liu J, Bai X, Yan G, Lu L. Threedimensional finite element analysis of the craniomaxillary complex during maxillary protraction with bone anchorage vs conventional dental anchorage. Am J Orthod Dentofacial Orthop $2013 ; \mathbf{1 4 3 : 1 9 7 - 2 0 5 .}$

5. Chen ZX, Pan XG, Chen ZQ. Maxillary protraction with and without maxillary expansion on unilateral cleft lip and palate model: a finite element analysis.Shanghai Kou Qiang Yi Xue. 2012;21:287-293.

6. Canales C, Larson M, Grauer D, Sheats R, Stevens C, Ko CC. A novel biomechanical model assessing continuous orthodontic archwire activation.Am J Orthod Dentofacial Orthop 2013; 143:281-190.

7. De Oliveira BF, Seraidarian PI, de Oliveira SG, Landre J J r, Pithon MM, Oliveira DD. Tooth displacement in shortened dental arches: a three-dimensional finite element study. J Prosthet Dent. 2014; 111(6):460-465.

8. Baswaraj, Hemanth $M$, J ayasudha, Patil C, Sunilkumar P, Raghuveer HP, Chandralekha B. An experimental study of arch perimeter and arch width increase with mandibular expansion: a finite element method. J Contemp Dent Pract.2013; 14:104-110.

9. Tominaga J Y, Chiang PC, Ozaki H, Tanaka M, Koga Y, Bourauel C, Yoshida N. Effect of play between bracket and archwire on anterior tooth movement in sliding mechanics: A three-dimensional finiteelement study.J Dent Biomech 2012; 3:1758736012461269.
10. An X, Chen H, Si Q, Zhou Y, Liu B, Wang J. A three dimensional finite element analysis on en-masse retraction of maxillary anterior teeth by rocking-chair archwire in sliding mechanics. Hua Xi Kou Qiang Yi Xue Za Zhi. 2013; 31:21-25.

11. Holberg C, Winterhalder P, Holberg N, Wichel haus A, Rudzki-J anson I. Indirect miniscrew anchorage: biomechanical loading of the dental anchorage during mandibular molar protraction-an FEM analysis.J Orofac Orthop 2014; 75:16-24.

12. Holberg C, Winterhalder P, Rudzki-J anson I, Wichel haus A. Finite element analysis of mono- and bicortical miniimplant stability. Eur J Orthod 2013.

13. Ludwig B, Baumgaertel S, Zorkun B, Bonitz L, Glasl B, Wilmes B, Lisson J . Application of a new viscoelastic finite element method model and analysis of miniscrew-supported hybrid hyrax treatment. Am J Orthod Dentofacial Orthop 2013; 143:426-435.

14. Boryor A, Hohmann A, Wunderlich A, Geiger M, Kilic F, Kim KB, Sander M, Bockers T, Sander C. Use of a modified expander during rapid maxillary expansion in adults: an in vitro and finite element study. Int J Oral Maxillofac Implants. 2013; 28:11-16.

15. Nienkemper M, Handschel J , Drescher D. Systematic review of mini-implant displacement under orthodontic loading. Int J Oral Sci. 2014; 6:1-6.

16. Lin TS, Tsai FD, Chen CY, Lin LW. Factorial analysis of variables affecting bone stress adjacent to the orthodontic anchorage mini-implant with finite element analysis. Am J Orthod Dentofacial Orthop. 2013; 143:182-189.

17. Meher AH, Shrivastav SS, Vibhute PJ, Hazarey PV. Deflection and stress distribution around mini-screw implants: a finite element investigation into the effect of cortical bone thickness, force magnitude and direction. J Orthod 2012; 39:249-255.

18. Lee J, Kim J Y, Choi YJ, Kim KH, Chung CJ. Effects of placement angleand direction of orthopedic force application on the stability of orthodontic miniscrews. Angle Orthod. 2013; 83:667-673.

19. Baek SH, Cha HS, Cha JY, Moon YS, Sung SJ. Threedimensional finite element analysis of the deformation of the human mandible: a preliminary study from the perspective of orthodontic mini-implant stability. Korean J Orthod 2012; 42:159-168.

20. Holberg C, Winterhalder P, Holberg N, Rudzki-J anson I, Wichel haus A. Direct versus indirect loading of orthodontic miniscrew implants-an FEM analysis. Clin Oral Investig.2013; 17:1821-1827. 
21. Kojima Y, Kawamura J, Fukui H. Finite element analysis of the effect of force directions on tooth movement in extraction space closure with miniscrew sliding mechanics. Am J Orthod Dentofacial Orthop 2012; 142:501-508.

22. Huang YW, Chang $\mathrm{CH}$, Wong TY, Liu J K. Bone stress when miniplates are used for orthodontic anchorage: finite element analysis. Am J Orthod Dentofacial Orthop 2012; 142:466-472.

23. Lee HJ , Lee KS, Kim MJ , Chun YS. Effect of bite force on orthodontic mini-implants in the molar region: Finite element analysis. Korean J Orthod 2013; 43:218.

24. Wang $\mathrm{H}$, Wu J Y, Zhou Q, Liu J.Initial stress in the periodontal membrane of maxillary first molar with different alveolar bone height by intrusion: 3-dimensional finite element analysis. Shanghai Kou Qiang Yi Xue 2013; 22:247251.

25. Geramy A, Etezadi T. Optimization of unilateral molar rotation correction by a transpalatal bar: a threedimensional analysis using the finite element method. J Orthod 2013; 40:197-205.

26. Viecilli RF, Kar-Kuri MH, Varriale J, Budiman A, J anal M. Effects of initial stresses and time on orthodontic external root resorption. J Dent Res 2013; 92:346-351.

27. Araugio RM, Landre J J r, Silva Dde L, Pacheco W, Pithon $M M$, Oliveira DD. Influence of the expansion screw height on the dental effects of the hyrax expander: a study with finite elements. Am J Orthod Dentofacial Orthop 2013; 143:221-7.

28. Sato FR, Asprino L, Consani S, Noritomi PY, de Moraes M. A comparative evaluation of the hybrid technique for fixation of the sagittal split ramus osteotomy in mandibular advancement by mechanical, photoelastic, and finite element analysis.Oral Surg Oral Med Oral Pathol Oral Radiol. 2012; 114:60-68.
29. Van Schepdael A, Geris L, Vander Sloten J. Analytical determination of stress patterns in the periodontal ligament during orthodontic tooth movement. Med Eng Phys 2013; 35:403-410.

30. Vikram NR, Senthil Kumar KS, Nagachandran KS, Hashir YM. Apical stress distribution on maxillary central incisor during various orthodontic tooth movements by varying cemental and two different periodontal ligament thicknesses: a FEM study. Indian J Dent Res 2012; 23:213-220.

31. Lin YL, Liu YH, Wang DM, Xu J W. Three-dimensional finite element analysis on the effect of posterior cross-bite of individual teeth on temporomandibular joint.Zhonghua Kou Qiang Yi Xue Za Zhi 2013; 48:86-90.

32. Geramy A. Bodily labializing lateral incisors: 3D analysis using finite element method. Acta Odontol Scand 2013; 71:570-576.

33. Huang Y, Keilig L, Rahimi A, Reimann S, Bourauel C. Torque capabilities of self-ligating and conventional brackets under the effect of bracket width and free wire length. Orthod Craniofac Res 2012; 15:255-262.

34. Holberg C, Winterhalder P, Holberg N, Wichelhaus A, Rudzki-J anson I. Orthodontic bracket debonding: risk of enamel fracture.Clin Oral Investig 2014; 18:327-334.

35. Zhang Y, Xia X, Deng F, Fan Y, Wang C, Huang Q. Analysis of tip back bend on initial displacement of the maxillary first molar in Tip-Edge force system by three-dimensional finite element method.Hua Xi Kou Qiang Yi Xue Za Zhi 2012; 30:329-332.

36. Chen S, Xu TM, Lou HD, Rong QG. Individualized threedimensional finite element model of facial soft tissue and preliminary application in orthodontics.Zhonghua Kou Qiang Yi Xue Za Zhi 2012; 47:730-734.

\section{Gain quick access to our journal online View our journal at} www.nacd.in 